\title{
Metabolic and functional effects of glutamate intake in patients with chronic obstructive pulmonary disease (COPD).
}

Citation for published version (APA):

Rutten, E. P., Engelen, M. P., Gosker, H. R., Bast, A., Cosemans, K., Vissers, Y. L., Wouters, E. F., Deutz, N. E., \& Schols, A. M. (2008). Metabolic and functional effects of glutamate intake in patients with chronic obstructive pulmonary disease (COPD). Clinical Nutrition, 27(3), 408-415. https://doi.org/10.1016/j.clnu.2008.03.001

Document status and date:

Published: 01/01/2008

DOI:

10.1016/j.clnu.2008.03.001

Document Version:

Publisher's PDF, also known as Version of record

\section{Document license:}

Taverne

Please check the document version of this publication:

- A submitted manuscript is the version of the article upon submission and before peer-review. There can be important differences between the submitted version and the official published version of record.

People interested in the research are advised to contact the author for the final version of the publication, or visit the DOI to the publisher's website.

- The final author version and the galley proof are versions of the publication after peer review.

- The final published version features the final layout of the paper including the volume, issue and page numbers.

Link to publication

\footnotetext{
General rights rights.

- You may freely distribute the URL identifying the publication in the public portal. please follow below link for the End User Agreement:

www.umlib.nl/taverne-license

Take down policy

If you believe that this document breaches copyright please contact us at:

repository@maastrichtuniversity.nl

providing details and we will investigate your claim.
}

Copyright and moral rights for the publications made accessible in the public portal are retained by the authors and/or other copyright owners and it is a condition of accessing publications that users recognise and abide by the legal requirements associated with these

- Users may download and print one copy of any publication from the public portal for the purpose of private study or research.

- You may not further distribute the material or use it for any profit-making activity or commercial gain

If the publication is distributed under the terms of Article $25 \mathrm{fa}$ of the Dutch Copyright Act, indicated by the "Taverne" license above, 


\title{
Metabolic and functional effects of glutamate intake in patients with chronic obstructive pulmonary disease (COPD)
}

\author{
Erica P.A. Rutten ${ }^{a, *}$, Marielle P.K.J. Engelen ${ }^{\text {b }}$, Harry Gosker ${ }^{a}$, \\ Aalt Bast $^{c}$, Kirsten Cosemans ${ }^{b}$, Yvonne L.J. Vissers ${ }^{b}$, \\ Emiel F.M. Wouters ${ }^{a}$, Nicolaas E.P. Deutz ${ }^{b}$, Annemie M.W.J. Schols ${ }^{a}$ \\ a Department of Respiratory Medicine, University of Maastricht, Maastricht, the Netherlands \\ ${ }^{\mathrm{b}}$ Department of Surgery, University of Maastricht, Maastricht, the Netherlands \\ c Department of Pharmacology and Toxicology, University of Maastricht, Maastricht, the Netherlands
}

Received 21 November 2007; accepted 4 March 2008

\author{
KEYWORDS \\ Skeletal muscle; \\ Glutathione; \\ Lactate; \\ Supplementation; \\ Quadriceps twitch force
}

\begin{abstract}
Summary
Background \& aims: Patients with chronic obstructive pulmonary disease (COPD) often suffer from skeletal muscle weakness due to muscle wasting and altered muscle metabolism. Decreased muscle glutamate concentration in COPD is consistently reported and is associated with decreased muscle glutathione concentration and early lactic acidosis. We hypothesized that an increased availability of glutamate via glutamate ingestion increases muscle glutamate concentration leading to acute improvements in skeletal muscle energy metabolism and function.

Methods: Two experiments were conducted. In experiment 1, in two groups of 6 male COPD patients ( $\mathrm{FEV}_{1}: 44.8 \pm 3.4 \%$ pred) and 6 healthy controls, blood samples and muscle biopsies were taken at 0 and 80 min after repeated glutamate $(30 \mathrm{mg} / \mathrm{kg} \mathrm{BW})$ or control ingestion $(1.25 \mathrm{ml} / \mathrm{kg} \mathrm{BW})$, and after $20 \mathrm{~min}$ cycling at $50 \%$ peak workload. In experiment 2 , in 10 COPD patients $\left(\mathrm{FEV}_{1}: 36.1 \pm 2.5 \%\right.$ pred $)$, the effect of the two drinks was tested on cycle endurance time and contractile quadriceps fatigue measured by magnetic stimulation before and after cycling at $75 \%$ peak workload.
\end{abstract}

Abbreviations: HAD, 3-hydroxyacyl dehydrogenase; CS, Citrate synthase; PFK, Phosphofructo kinase; GSH, reduced glutathione; GSSG, oxidized glutathione.

* Corresponding author: CIRO Horn, Research, Development and Education, P.O. Box 4080, 6080 AB Haelen, the Netherlands. Tel.: +3147 558 7651; fax: +31 475587592.

E-mail addresses: ericarutten@proteion.nl (E.P.A. Rutten), mpkj.engelen@ctral.org (M.P.K.J. Engelen), h.gosker@pul.unimaas.nl (H. Gosker), a.bast@farmaco.unimaas.nl (A. Bast), ylj.vissers@ah.unimaas.nl (Y.L.J. Vissers), e.wouters@lung.azm.nl (E.F.M. Wouters), nep. deutz@ctral.org (N.E.P. Deutz), a.schols@pul.unimaas.nl (A.M.W.J. Schols). 
Results: Glutamate ingestion increased plasma $(p<0.01)$ but not muscle glutamate concentration. Muscle total and reduced glutathione and plasma lactate concentration were not affected by glutamate ingestion. Glutamate ingestion did not influence contractile muscle fatigue and endurance time.

Conclusion: Continuous oral glutamate ingestion for $80 \mathrm{~min}$ did not lead to an acute effect on skeletal muscle substrate metabolism and muscle performance in COPD patients and in agematched healthy controls.

(c) 2008 Elsevier Ltd and European Society for Clinical Nutrition and Metabolism. All rights reserved.

\section{Introduction}

Chronic obstructive pulmonary disease (COPD) is a serious and common disease and a high burden for health care. Dominant symptoms are dyspnea and exercise intolerance progressively disabling patients and leading to a poor quality of life. ${ }^{1}$ In addition to the lung function impairment, quadriceps muscle weakness is an important determinant of exercise intolerance ${ }^{2}$ due to muscle wasting and altered muscle metabolism. A reduced aerobic capacity has consistently been reported in patients with moderate to severe COPD reflected by a shift from type I to type IIx fibers ${ }^{3}$ and reduced activity of oxidative enzymes. ${ }^{4}$

In addition, a decreased skeletal muscle glutamate concentration has repeatedly been reported in patients with COPD. ${ }^{5,6}$ In this patient group, low resting muscle glutamate levels were associated with decreased muscle glutathione levels, ${ }^{7}$ and with early lactic acidosis during maximal cycle ergometry. ${ }^{8}$ Glutamate is largely taken up by muscle at rest ${ }^{9}$ and even to a higher extent during exercise. ${ }^{10}$ Moreover, during the first minutes of exercise, muscle glutamate concentration decreases, ${ }^{11}$ suggesting that glutamate acts as an important intermediate in substrate metabolism during exercise.

It was elegantly demonstrated that some COPD patients develop contractile quadriceps fatigue during exercise, defined as a reversible post-exercise fall in quadriceps muscle strength measured by magnetic stimulation. ${ }^{12}$ In contrast to the non-fatiguers, cycle endurance time did not improve after nebulization of a bronchodilator. ${ }^{13}$ Furthermore, the fatiguers were characterized by increased lactate dehydrogenase activities and higher exercise-induced plasma lactate levels compared to the non-fatiguers, despite similar fiber type distribution and oxidative enzyme activities. ${ }^{14}$ These findings suggest that glycolytic metabolism is enhanced in this subgroup of COPD patients due to less substrate availability rather than to morphologic alterations.

In a previous study, we showed that the availability of glutamate for the skeletal muscle increases after continuous glutamate ingestion for $80 \mathrm{~min} .{ }^{15}$ In addition, although it is expected that a large amount of the amino acid is absorbed and metabolized by the splanchnic area, ${ }^{16}$ Graham et al. showed that a bolus oral glutamate ingestion was able to increase skeletal muscle glutamate concentration in young healthy volunteers. ${ }^{17}$ Therefore, we hypothesized that increasing substrate availability in COPD patients by oral glutamate ingestion increases skeletal muscle glutamate concentration, resulting in sharp improvements in muscle metabolism and performance.
We conducted two experiments to test our hypothesis. In the first experiment, we investigated if repeated glutamate ingestion increases muscle glutamate concentration in patients with COPD and age-matched healthy volunteers. Moreover, based on the previously reported associations between muscle glutamate, muscle glutathione and plasma lactate response during exercise, the effect of repeated glutamate ingestion was evaluated on these substrates at rest and after submaximal cycle ergometry. In the second experiment, the acute effect of glutamate ingestion was evaluated on contractile quadriceps fatigue and cycle endurance time.

\section{Materials and methods}

\section{Study population}

All patients recruited in experiment $1(n=12)$ and 2 $(n=16)$ had COPD according to GOLD guidelines ${ }^{18}$ defined as measured forced expiratory volume in 1 second $\left(\mathrm{FEV}_{1}\right)$ $<70 \%$ of reference $\mathrm{FEV}_{1}$. Exclusion criteria for all subjects were malignancy, cardiac failure, distal arteriopathy, recent surgery, severe endocrine, hepatic or renal disorder. Also, patients who were using systemic corticosteroids within 3 months prior to the study were excluded as it has been shown that systemic corticosteroids may affect muscle protein metabolism. ${ }^{19}$ The medical ethical committee of the University Hospital Maastricht approved both experiments and all subjects obtained written informed consent.

\section{Test drink}

All subjects ingested the glutamate (Ajinomoto ${ }^{\circledR}$, Japan) drink in accordance with our previous conducted protocol of $30 \mathrm{mg}$ glutamate ingestion per kg body weight (BW) every 20 min for 80 min, which was shown showed to be able to increase glutamate delivery to muscle. ${ }^{17}$ The control drink was an equal amount of only water $(1.25 \mathrm{ml}$ water per $\mathrm{kg}$ BW every $20 \mathrm{~min})$. The drinks were flavored with sweetener and served at $55{ }^{\circ} \mathrm{C}$ to assure complete dissolution. As the same ingestion protocol was used in other metabolic studies including stable isotopes, the ingestion was continued for $80 \mathrm{~min}$ (5 ingestions).

\section{Characterization of the study group}

\section{Body composition}

In all subjects, body weight and height were measured by using an electronic beam scale with digital readout to the 
nearest $0.1 \mathrm{~kg}$ (model 708; Seca, Hamburg, Germany) and to the nearest $0.1 \mathrm{~cm}$ (model 220, Seca) respectively. Whole-body fat-free mass (FFM) was measured in each subject using bio-electrical impedance analyses (BIA) (Xitron 4000B, Xitron Technologies, San Diego, CA). FFM of the COPD patients was calculated using a regression equation developed for COPD patients, ${ }^{20}$ whereas FFM of the healthy controls was calculated using a specific regression equation for elderly men as described by Dey et al. ${ }^{21}$

\section{Pulmonary function tests}

All subjects underwent spirometry for determination of $\mathrm{FEV}_{1}$ and forced vital capacity (FVC) with the highest value from at least three technically acceptable maneuvers being used. Diffusion capacity for carbon monoxide $\left(\mathrm{DL}_{\mathrm{co}}\right)$ was measured using the single-breath method (Masterlab; Jaeger, Wurzburg, Germany). All values obtained were related to a reference value and expressed as percentages of the predicted value. ${ }^{22}$

\section{Incremental cycle ergometry}

In order to determine each subject's peak workload, all subjects performed a symptom limited incremental cycle ergometer test under supervision of a physician. After $1 \mathrm{~min}$ of unloaded cycling power, power was increased by $10 \mathrm{~W}$ every minute for the COPD patients. For control subjects, the load was increased by $15-25 \mathrm{~W}$ every minute, so that the duration of the exercise test was comparable for the two groups. None of the subjects knew the exercise load and all were encouraged to cycle at $60 \mathrm{rrevs} / \mathrm{min}$ until exhaustion. Peak workload was monitored at the end of the exercise.

\section{Study design}

\section{Experiment 1}

Two groups of 6 male COPD patients $\left(\mathrm{FEV}_{1}\right.$ : $44.8 \pm$ $3.4 \%$ pred) and 6 age- and sex-matched healthy control subjects, recruited by a local magazine, ingested the glutamate drink or the control drink after overnight fast. The ingestion of the drinks was single-blinded and administered in randomized fashion. In the morning after $1 \mathrm{~h}$ of rest, all subjects started to ingest the test drink for 80 min (Fig. 1A). Subsequently, submaximal cycle ergometry was performed on $50 \%$ of subject's peak workload for $20 \mathrm{~min}$. Blood samples and muscle biopsies were taken just before the ingestion period, and just before and after the ergometry to analyze plasma glutamate and lactate concentrations, and skeletal muscle glutamate and glutathione concentrations, respectively. Muscle biopsies were taken from the lateral part of the quadriceps femoris by using the needle-biopsy technique ${ }^{23}$ after administration of local anesthetic while the subjects lay in a supine position. The first biopsy was taken in the non-dominant leg; the second in the other leg, and the third biopsy was taken in the same incision as the second biopsy.

\section{Biochemical analyses}

Blood was collected in a heparinized tube, immediately put on ice and centrifuged $\left(3120 \times \mathrm{g}, 4^{\circ} \mathrm{C}\right.$ for $\left.10 \mathrm{~min}\right)$ to obtain plasma. Subsequently, $250 \mu \mathrm{l}$ plasma was deproteinized

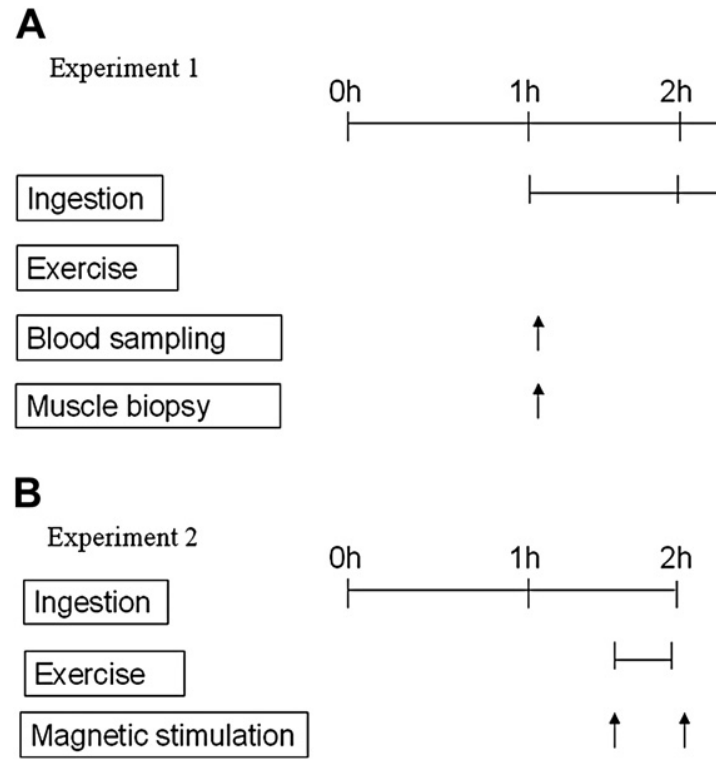

Figure 1 Schematic overview of the study design of experiments 1 and 2. (A) After overnight fast and $1 \mathrm{~h}$ rest, the subjects started to ingest the test drink. Eighty minutes after the first ingestion, submaximal cycle ergometry was performed on $50 \%$ of subject's peak workload for $20 \mathrm{~min}$. Blood samples and muscle biopsies were taken just before the ingestion period, and just before and after the ergometry. (B) On two different test days, subjects ingested the glutamate or the control drink every $20 \mathrm{~min}$ for $80 \mathrm{~min}$. Subsequently, the subjects performed a submaximal cycle ergometer test of $75 \%$ of their peak workload until voluntary exhaustion. Subject's quadriceps twitch force (TwQ) was measured just before and after the exercise test using a magnetic stimulator.

with $20 \mathrm{mg}$ dry sulfosalicylic acid to analyze plasma glutamate concentration. Another $900 \mu \mathrm{l}$ plasma was deproteinized with $90 \mu \mathrm{l}$ trichloroacetic acid to examine plasma lactate concentration. All blood samples and muscle biopsies were frozen in liquid nitrogen and stored at $-80^{\circ} \mathrm{C}$ until analysis. Before analyses, part of the biopsies was dissolved in $250 \mu \mathrm{l}$ sulfosalicylic acid solution and beated with glass parts. Subsequently, samples were centrifuged $\left(3120 \times \mathrm{g}, 4^{\circ} \mathrm{C}\right.$ for $\left.10 \mathrm{~min}\right)$ and the supernatant was used for analyses. Plasma and muscle glutamate concentrations were analyzed by a high-performance liquid chromatography (HPLC) system. ${ }^{24}$ Plasma lactate concentration was analyzed by COBAS Mira S (Roche Diagnostica, Hoffman-La Roche, Basel, Switzerland). In baseline muscle biopsies, enzyme activities and myosin heavy chain (MyHC) isoforms were analyzed for characterization of the study groups. All samples were centrifuged $\left(10,000 \times g, 4^{\circ} \mathrm{C}\right.$ for $\left.10 \mathrm{~min}\right)$ and the supernatant was used for enzyme activity assays. Citrate synthase (CS), 3-hydroxyacyl-CoA dehydrogenase (HAD) and phospho-fructo kinase (PFK) were analyzed spectrophotometrically (Multiskan Spectrum, Thermo Labsystems, Breda, The Netherlands). The remaining pellet was resuspended in three volumes of ice-cold extraction buffer (100 mM Na${ }_{4} \mathrm{O}_{7} \mathrm{P}_{2} \cdot 10 \mathrm{H}_{2} \mathrm{O}, 5 \mathrm{mM}$ EDTA, $1 \mathrm{mM}$ DTT, pH 8.5), incubated on ice for $30 \mathrm{~min}$, and centrifuged $(10,000 \times \mathrm{g}$, $4{ }^{\circ} \mathrm{C}$ for $10 \mathrm{~min}$ ). From this, the supernatant was used for 
MyHC isoform analysis as described by Talmadge and Roy. ${ }^{25}$ Muscle reduced and oxidized glutathione (GSH and GSSG respectively) were measured according to Vandeputte et al. ${ }^{26}$

\section{Experiment 2}

Prior to the test, clinically stable COPD patients $\left(\mathrm{FEV}_{1}\right.$ : $36.1 \pm 2.5 \%$ pred) performed cycle ergometry at $75 \%$ of their peak workload until voluntary exhaustion. Subjects' quadriceps twitch force (TwQ) was measured just before and after the exercise test using a magnetic stimulator to assess contractile quadriceps muscle fatigue. Quadriceps twitch force was measured by stimulation of the femoral nerve with a magnetic stimulator (Magstim $200^{\circledR}$; Magstim Co. Ltd., Whitland, Dyfed, Wales, UK) using a 45-mm figure-of-eight coil, described before. ${ }^{13} \mathrm{~A}$ series of 22 twitches were randomly obtained at $60 \%, 80 \%, 90 \%, 95 \%$ and $100 \%$ of power output to assure supramaximal stimulation. After every twitch, a resting period of $20 \mathrm{~s}$ assured depolarization of the quadriceps muscle. The average of the outputs at $100 \%$ was used as the TwQ. In total, 16 COPD patients were screened and 10 patients ( 8 male) who developed contractile quadriceps muscle fatigue (decrease in quadriceps twitch force of $\geq 15 \%{ }^{12}$ ) were included in experiment 2. The study involved two different test days at least 1 week apart, during which time the glutamate or the control drink was ingested in randomized and singleblinded order. After an overnight fast, subjects started to sip the test drink every $20 \mathrm{~min}$ for $80 \mathrm{~min}$ (Fig. 1B). Subsequently, the subjects performed cycle ergometry of $75 \%$ of their peak workload until voluntary exhaustion. Subjects' quadriceps twitch force (TwQ) was measured just before and after the exercise test. Cycle endurance time and the exercise-induced fall in TwQ were determined as outcome measurements.

\section{Statistical analyses}

Data were checked for normality and presented as mean \pm SEM. The power of the two studies was calculated to measure effects in time and not for cross-sectional comparisons. In experiment 1 , the Student $t$-test was used to ascertain whether general characteristics were significantly different between the COPD patients and control subjects. Repeated measurements ANOVA test with within variables time (baseline, $80 \mathrm{~min}$ ingestion, $20 \mathrm{~min}$ exercise) and between variables group (COPD and control group) and drink (glutamate and control ingestion) was performed to test effects on plasma and muscle substrate concentrations. If there was a significant interaction for time $\times$ group or time $\times$ drink, the effect in time was tested within each group or drink. In experiment 2, the paired Student $t$-test was used to test differences in endurance time and the amount of exercise-induced fall in TwQ between the two drinks. The statistical package SPSS for Windows (Version 11.0, SPSS Inc., Chicago, IL, USA) was used for data analysis. A $p$-value of $<0.05$ was considered statistically significant.

\section{Results}

There was no difference in body composition between the COPD patients and the control subjects in experiment 1 (Table 1). The patients were characterized by decreased

Table 1 Baseline characteristics of the healthy control subjects and COPD patients included in experiments 1 and $2^{\mathrm{a}}$

\begin{tabular}{|c|c|c|c|}
\hline & \multicolumn{2}{|l|}{ Experiment 1} & \multirow{2}{*}{$\begin{array}{l}\text { Experiment } 2 \\
\text { COPD patients }\end{array}$} \\
\hline & Controls & COPD patients ${ }^{\mathrm{b}}$ & \\
\hline Amount & 12 & 12 & 10 \\
\hline Age, years & $61.4 \pm 1.6$ & $66.7 \pm 1.4$ & $61.5 \pm 3.4$ \\
\hline Weight, kg & $76.5 \pm 2.9$ & $72.1 \pm 4.2$ & $78.8 \pm 4.8$ \\
\hline $\mathrm{BMI}, \mathrm{kg} / \mathrm{m}^{2}$ & $25.3 \pm 0.7$ & $23.3 \pm 0.9$ & $25.5 \pm 1.5$ \\
\hline FFMI, $\mathrm{kg} / \mathrm{m}^{2}$ & $18.9 \pm 0.3$ & $18.1 \pm 0.4$ & $18.6 \pm 0.7$ \\
\hline FVC, \%pred & $117.9 \pm 4.7$ & $87.4 \pm 20.0^{* *}$ & $86.8 \pm 5.5$ \\
\hline Dlco, \%pred & $113.4 \pm 6.2$ & $67.1 \pm 7.0^{*}$ & $41.4 \pm 4.9$ \\
\hline Wpeak, Watt & $201.7 \pm 18.3$ & $97.3 \pm 10.0^{* *}$ & $75.6 \pm 6.5$ \\
\hline Muscle glutamate concentration, $\mu \mathrm{mol} / \mathrm{kg}$ ww & $2338.3 \pm 209.5$ & $2038.9 \pm 151.3$ & \\
\hline Citrate synthetase, $\mathrm{U} / \mathrm{mg}$ protein & $39.1 \pm 6.9$ & $29.3 \pm 6.3$ & \\
\hline 3-Hydroxy-acyl dehydrogenase, U/mg protein & $91.5 \pm 9.4$ & $56.2 \pm 10.9^{*}$ & \\
\hline Phospho-fructo kinase, U/mg protein & $576.1 \pm 82.1$ & $423.6 \pm 126.6$ & \\
\hline \% MyHC type I fibers & $37.6 \pm 1.5$ & $40.1 \pm 3.0$ & \\
\hline \% MyHC type Ila fibers & $49.7 \pm 1.6$ & $47.5 \pm 1.9$ & \\
\hline \% MyHC type IIx fibers & $13.3 \pm 2.0$ & $13.8 \pm 2.5$ & \\
\hline TwQ, kg & & & $7.6 \pm 0.8$ \\
\hline Quadriceps fatigue, \% & & & $27.7 \pm 3.7$ \\
\hline Endurance time, min & & & $7.2 \pm 0.7$ \\
\hline
\end{tabular}


exercise capacity (peak workload COPD patients $=51.8 \%$ peak workload controls) and reduced muscle HAD concentration $(p<0.05)$, indicating a decreased fat oxidative capacity. Muscle glutamate, CS and PFK concentration tended to be lower in the patients, but they did not reach significance.

Baseline plasma glutamate concentration and the effects of the drinks on plasma glutamate concentration were not different between the patients with COPD and the control subjects. Glutamate ingestion resulted in a significant increased plasma glutamate concentration $(p<0.01$, Table 2), but skeletal muscle glutamate concentration remained unchanged. Exercise resulted in a decreased plasma glutamate concentration after control ingestion $(p<0.05)$, and a decreased muscle glutamate concentration independent of the ingestion $(p<0.01)$. Baseline skeletal muscle total glutathione, GSH or GSSG concentrations and the effects on the drinks were not different between the groups. Glutamate ingestion did not affect muscle total glutathione, GSH and GSSG concentrations at rest or during exercise (Table 2). However in the control subjects during exercise, muscle GSSG concentration significantly increased $(p<0.05)$. Glutamate ingestion had no effect on plasma lactate concentration during exercise. Plasma lactate concentration increased in both groups during exercise, but to a higher level in the patients compared to the control subjects $(p<0.05$, Table 2$)$. In experiment 2 , there was no effect of the treatment on mean cycle endurance time and contractile muscle fatigue (Fig. 2).

\section{Discussion}

Although plasma glutamate concentration and thus the availability of glutamate for the skeletal muscle significantly increased after oral glutamate ingestion, no effect of glutamate ingestion on skeletal muscle glutamate, glutathione and plasma lactate concentrations in patients with COPD and healthy control subjects were found in the present study. In addition, no effects of oral glutamate ingestion on contractile muscle fatigue and cycle endurance time could be found.

The main hypothesis of the present research was that oral glutamate ingestion increases muscle glutamate concentration in clinically stable COPD patients, leading to

Table 2 Plasma and skeletal muscle glutamate and glutamate-related substrate concentration at baseline (T0), after 80 min continuous glutamate ingestion (T80) and after 20 min submaximal cycle ergometry (T100)

\begin{tabular}{|c|c|c|c|c|c|}
\hline \multirow[t]{2}{*}{ Amino acid } & \multirow[t]{2}{*}{ Group } & \multirow[t]{2}{*}{ Ingestion $^{f}$} & \multicolumn{3}{|l|}{ Time (min) } \\
\hline & & & $\overline{\mathrm{TO}}$ & T80 & $\mathrm{T} 100^{\mathrm{a}}$ \\
\hline \multirow[t]{4}{*}{ Plasma glutamate concentration $(\mu \mathrm{mol} / \mathrm{L})^{\mathrm{b}}$} & Control & Wa & $97 \pm 10$ & $112 \pm 5$ & $82 \pm 4$ \\
\hline & & GLU & $95 \pm 25$ & $438 \pm 78$ & $384 \pm 62$ \\
\hline & COPD & Wa & $97 \pm 13$ & $100 \pm 6$ & $83 \pm 6$ \\
\hline & & GLU & $85 \pm 6$ & $629 \pm 71$ & $553 \pm 97$ \\
\hline \multirow[t]{4}{*}{ Muscle glutamate concentration $(\mu \mathrm{mol} / \mathrm{kg} \mathrm{ww})^{c}$} & Control & Wa & $2118 \pm 294$ & $2538 \pm 300$ & $2116 \pm 513$ \\
\hline & & GLU & $2559 \pm 295$ & $2349 \pm 307$ & $1784 \pm 429$ \\
\hline & COPD & Wa & $1808 \pm 160$ & $1713 \pm 270$ & $1134 \pm 198$ \\
\hline & & GLU & $2270 \pm 232$ & $2357 \pm 144$ & $1896 \pm 110$ \\
\hline \multirow[t]{4}{*}{ Muscle total glutathione concentration ( $\mu \mathrm{mol} / \mathrm{kg} \mathrm{ww})$} & Control & Wa & $431 \pm 46$ & $534 \pm 92$ & $693 \pm 77$ \\
\hline & & GLU & $643 \pm 62$ & $586 \pm 24$ & $670 \pm 145$ \\
\hline & COPD & Wa & $673 \pm 68$ & $562 \pm 77$ & $673 \pm 134$ \\
\hline & & GLU & $554 \pm 28$ & $549 \pm 26$ & $495 \pm 42$ \\
\hline \multirow[t]{4}{*}{ Muscle GSSG concentration $(\mu \mathrm{mol} / \mathrm{kg} \mathrm{ww})^{\mathrm{d}}$} & Control & Wa & $70 \pm 6$ & $76 \pm 10$ & $176 \pm 35$ \\
\hline & & GLU & $38 \pm 12$ & $45 \pm 17$ & $82 \pm 22$ \\
\hline & COPD & Wa & $130 \pm 17$ & $123 \pm 22$ & $145 \pm 37$ \\
\hline & & GLU & $26 \pm 6$ & $41 \pm 14$ & $37 \pm 14$ \\
\hline \multirow{4}{*}{ Muscle GSH concentration ( $\mu \mathrm{mol} / \mathrm{kg}$ ww) } & Control & Wa & $291 \pm 55$ & $382 \pm 86$ & $341 \pm 108$ \\
\hline & & GLU & $566 \pm 67$ & $496 \pm 32$ & $505 \pm 114$ \\
\hline & COPD & Wa & $314 \pm 70$ & $316 \pm 57$ & $345 \pm 154$ \\
\hline & & GLU & $502 \pm 33$ & $467 \pm 50$ & $421 \pm 65$ \\
\hline \multirow[t]{4}{*}{ Plasma lactate concentration $(\mathrm{mmol} / \mathrm{L})^{\mathrm{e}}$} & Control & $\mathrm{Wa}$ & $1.58 \pm 0.20$ & $0.98 \pm 0.7$ & $1.25 \pm 0.49$ \\
\hline & & GLU & $1.56 \pm 0.18$ & $0.94 \pm 0.8$ & $2.1 \pm 0.94$ \\
\hline & COPD & Wa & $1.59 \pm 0.27$ & $1.32 \pm 0.32$ & $3.36 \pm 0.33$ \\
\hline & & GLU & $1.66 \pm 0.23$ & $1.28 \pm 0.17$ & $3.34 \pm 0.4$ \\
\hline
\end{tabular}

\footnotetext{
a Values are mean \pm SEM.

b Plasma glutamate concentration: significant time $\times$ drink interaction. Water drink: significant effect from T80 to T100; Glutamate drink: significant effect from T0 to T80; both $p<0.01$.

c Muscle glutamate concentration: time effect between T80 and T100: $p<0.05$.

d Muscle GSSG concentration: significant time $\times$ group interaction. Within the control group; significant time effect: $p<0.01$.

e Plasma lactate concentration: significant time $\times$ group interaction. Within the control group: significant time effect between T80 and T100, $p<0.05$. COPD group: significant time effect between T80 and T100, $p<0.01$.

f Abbreviations: GSSG, oxidized glutathione concentration; GSH, reduced glutathione concentration; Wa, water ingestion; GLU, glutamate ingestion.
} 


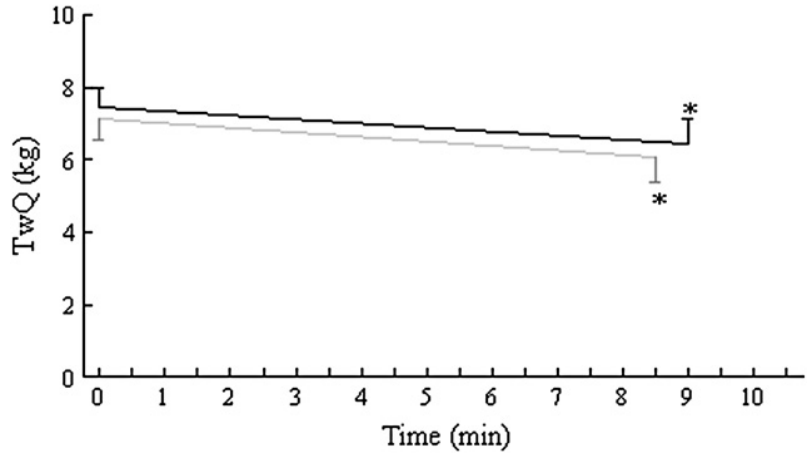

Figure 2 Mean exercise duration and quadriceps twitch force before and after a submaximal cycle ergometry after ingesting the water (dashed line) or glutamate drink (solid line) in COPD patients. Significant different from baseline: ${ }^{*} p<0.05$.

metabolic and functional improvements. In our patient group, baseline skeletal muscle glutamate concentration was not different compared to the control subjects. The power calculation of the present study was based on the effects in time and not for cross-sectional comparisons. Nevertheless, the COPD patients were characterized by a mildly reduced fat oxidative capacity, suggesting that muscle metabolism in this group was relatively preserved. In addition, previous research that showed a decreased skeletal muscle glutamate concentration in COPD patients included a more severe patient group characterized by emphysema and reduced BW and FFM. ${ }^{5}$ It can be speculated that a decreased muscle glutamate concentration and the related abnormal substrate metabolism is more pronounced in severe COPD patients with altered body composition.

Repeated ingestion of $30 \mathrm{mg}$ glutamate per kilogram BW every 20 min for 80 min did not induce an increased skeletal muscle glutamate concentration. In contrast, Graham et al. ${ }^{27}$ showed an increased muscle glutamate concentration of about $40 \%$ per kilogram dry weight after a bolus ingestion of $150 \mathrm{mg}$ monosodium glutamate per kilogram BW in young healthy volunteers. The continuous ingestion of glutamate in the present study differs from the bolus ingestion in the study by Graham et al., but the increase in plasma glutamate concentration was comparable between both studies (up to about $533 \mu \mathrm{mol} / \mathrm{L}$ in the present study vs. about $450 \mu \mathrm{mol} / \mathrm{L}$ in the study by Graham et al.), indicating that glutamate availability for skeletal muscle increases to an equal amount for both study groups by glutamate ingestion. Muscular glutamate uptake happens via a Na-dependent $X^{-}$ag-transport mechanism. The transporter is characterized by a low-activity high affinity, and it can be suggested that the transporter is not able to respond directly to the high plasma glutamate concentration. However, the $K_{\mathrm{m}}$ of the transport mechanism is $1000 \mu \mathrm{mol} /$ $\mathrm{L}$ and the $V_{\max }=80 \mu \mathrm{mol} / \mathrm{kg} \mathrm{ww}$ per/minute. Normal plasma glutamate concentration is about $60 \mu \mathrm{mol} / \mathrm{L}$, suggesting a linear relation between plasma glutamate concentration and muscular glutamate uptake. A plasma glutamate increase of about 5 times (up to about $500 \mu \mathrm{mol} / \mathrm{L}$ ), half of the maximum transport rate, is not even reached, indicating that this plasma concentration would not be the limiting step in the muscular glutamate uptake. Nevertheless, as

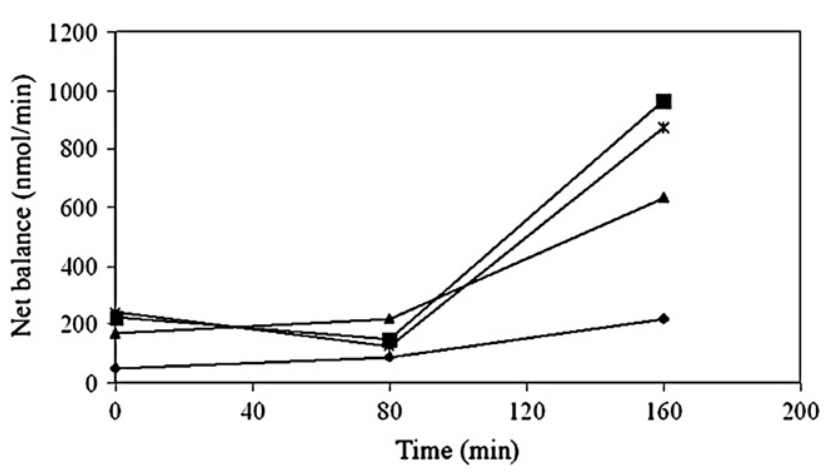

Figure 3 Data of a pilot study performed in four healthy elderly volunteers: individual arterio-venous net balances across the forearm after 80 min water ingestion followed by $80 \mathrm{~min}$ ingestion of a glutamate drink. A repeated measurement ANOVA test was performed with within variable time to detect effects in time: $p<0.05$.

glutamate metabolism is age-dependent ${ }^{28}$ and the volunteers in the study by Graham et al. were younger than the present subjects (mean age of 26 years), we cannot exclude an age-dependent effect on muscular glutamate uptake or metabolism. However, in a recent pilot study, we measured the arterio-venous balance across the forearm of 4 elderly volunteers during $80 \mathrm{~min}$ water ingestion $(1.25 \mathrm{ml}$ water per $\mathrm{kg}$ BW every $20 \mathrm{~min})$ followed by 80 min glutamate ingestion ( $30 \mathrm{mg}$ glutamate per kg BW every $20 \mathrm{~min}$, Fig. 3). These data indicate that a significant amount of ingested glutamate was indeed taken up by the skeletal muscle $(p<0.01)$, but is apparently not reflected in its concentration. Intramuscular glutamate metabolism can overwhelm the increase in muscle glutamate concentration. High glutamate intramuscular activity should be reflected in the concentration of its products. In the present study, muscle total and reduced glutathione concentrations were not affected by glutamate ingestion, implying that at least also other substrates than glutamate are involved in the rate-limiting step of muscle glutathione synthesis. Correlations between muscle glutathione and glutamate concentrations have been shown frequently. ${ }^{29}$ Until now, however, no agreement has been reached regarding the rate-limiting precursor in the glutathione synthesis, and glutamate as well as cysteine have been suggested. ${ }^{30}$

Previously, decreased skeletal muscle glutamate concentration in patients with COPD was associated with early lactic acidosis during exercise. ${ }^{8}$ As during exercise the activity of the alanine amino transferase reaction increases, ${ }^{31}$ we hypothesized that increasing the glutamate availability leads to a higher alanine and lower lactate production from pyruvate (alanine $+\alpha$-ketoglutarate $\leftrightarrow$ glutamate + pyruvate $\rightarrow$ lactate). Glutamate ingestion for $80 \mathrm{~min}$, however, did not affect plasma lactate concentrations after exercise, in line with plasma and muscle alanine concentrations (data not shown). Other studies that intended to modulate aerobic energy metabolism were also unable to show an effect on plasma lactate concentration, ${ }^{32}$ suggesting a well-controlled mechanism between the lactate production, consumption in the active skeletal muscle and clearance in the liver. 
None of the concentrations of the glutamate related substrates measured in the present study were affected by continuous glutamate ingestion. As research by Stegink et al. ${ }^{33}$ showed that intestinal carbohydrates increase the intestinal metabolic capacity of glutamate, the subjects in the present study started to ingest the test drink in the postabsorptive state. However, during short-term starvation whole-body glucose oxidation decreases ${ }^{34}$ while the contribution of gluconeogenesis to the energy consumption increases. ${ }^{35}$ Therefore, it is likely that glutamate is primarily used as energy source before a precursor for other substrates in the fasted state. In contrast to other amino acids, glutamate may be a preferably oxidative amino acid as it can act as a precursor for the tricarboxylic acid intermediate (TCAI) $\alpha$-ketoglutarate. It would be interesting in future studies to investigate the effect of glutamate as adjunct to a meal.

Because Saey et al. ${ }^{14}$ showed that the fatiguers had higher glycolytic metabolism compared to non-fatiguers, we evaluated the effects of glutamate ingestion on contractile quadriceps fatigue and cycle endurance time in fatiguers. We hypothesized that glutamate supplementation increases the oxidative metabolism, and thereby decreases lactate production and delays lactic acidosis during exercise, resulting in less quadriceps fatigue and higher endurance time. However, in line with our metabolic findings, glutamate ingestion had no effect on contractile quadriceps fatigue or endurance time. The cycle exercise protocol used in the present study was adapted from a previously employed protocol. ${ }^{12}$ However, in order to exclude the effect and variability of ventilatory limitation on endurance time and indirectly on quadriceps muscle fatigue, it would be interesting in future studies to compare this test with a local quadriceps muscle exercise test.

In conclusion, although oral glutamate ingestion in the postabsorptive state significantly increased plasma glutamate concentration and the availability of glutamate for skeletal muscle, we were not able to detect acute effects on skeletal muscle glutamate concentration or glutamaterelated substrates at rest and after exercise in COPD patients and age-matched healthy control subjects.

\section{Conflict of interest statement}

Each author states that there is no financial or personal interest in any company or organization sponsoring the research.

\section{Acknowledgments}

This study was supported by a grant from the Netherlands Asthma Foundation NAF: 3.2.0034, a research fellowship from ESPEN Nestlé 2003 and a European Union grant QLK6CT-2002-02285. The contribution of the authors to the manuscript is as follows: E.P.A.R.: study design, data collection, data analysis and writing the manuscript; K.C.: data collection and data analysis; N.E.P.D.: data collection, data analysis and reviewing the manuscript; Y.L.J.V.: data collection; A.B. and H.G.: data analysis and reviewing the manuscript; M.P.K.J.E., E.F.M.W. and A.M.W.J.S.: study design and reviewing the manuscript.

\section{References}

1. Franssen FM, Broekhuizen R, Janssen PP, et al. Effects of whole-body exercise training on body composition and functional capacity in normal-weight patients with COPD. Chest 2004;125:2021-8.

2. Decramer M, Gosselink R, Troosters T, et al. Muscle weakness is related to utilization of health care resources in COPD patients. Eur Respir J 1997;10:417-23.

3. Gosker HR, van Mameren H, van Dijk PJ, et al. Skeletal muscle fibre-type shifting and metabolic profile in patients with chronic obstructive pulmonary disease. Eur Respir J 2002;19:617-25.

4. Maltais F, LeBlanc $P$, Whittom $F$, et al. Oxidative enzyme activities of the vastus lateralis muscle and the functional status in patients with COPD. Thorax 2000;55:848-53.

5. Engelen MP, Wouters EF, Deutz NE, et al. Factors contributing to alterations in skeletal muscle and plasma amino acid profiles in patients with chronic obstructive pulmonary disease. Am J Clin Nutr 2000;72:1480-7.

6. Pouw EM, Schols AMWJ, Deutz NEP, et al. Plasma and muscle amino-acid levels in relation to resting energy expenditure and inflammation in stable COPD. Am J Respir Crit Care Med 1998; 158:797-801.

7. Engelen MPKJ, Schols AMWJ, Does JD, et al. Altered glutamate metabolism is associated with reduced muscle glutathione levels in patients with emphysema. Am J Respir Crit Care Med 2000;161:98-103.

8. Engelen MPKJ, Schols AMWJ, Does JD, et al. Exercise induced lactate increase in relation to muscle substrates in patients with COPD. Am J Respir Crit Care Med 2000;162:1697-704.

9. Marliss EB, Aoki TT, Pozefsky T, et al. Muscle and splanchnic glutamine and glutamate metabolism in postabsorptive and starved man. J Clin Invest 1971;50:814-7.

10. Van Hall G, Saltin B, Wagenmakers AJ. Muscle protein degradation and amino acid metabolism during prolonged kneeextensor exercise in humans. Clin Sci (Lond) 1999;97:557-67.

11. Gibala MJ, MacLean DA, Graham TE, et al. Anaplerotic processes in human skeletal muscle during brief dynamic exercise. J Physiol 1997;502(Pt 3):703-13.

12. Mador MJ, Kufel TJ, Pineda L. Quadriceps fatigue after cycle exercise in patients with chronic obstructive pulmonary disease. Am J Respir Crit Care Med 2000;161:447-53.

13. Saey $D$, Debigare $R$, LeBlanc $P$, et al. Contractile leg fatigue after cycle exercise: a factor limiting exercise in patients with chronic obstructive pulmonary disease. Am J Respir Crit Care Med 2003;168:425-30.

14. Saey D, Michaud A, Couillard A, et al. Contractile fatigue, muscle morphometry, and blood lactate in chronic obstructive pulmonary disease. Am J Respir Crit Care Med 2005;171:1109-15.

15. Rutten EP, Engelen MP, Wouters EF, et al. Effect of glutamate ingestion on whole-body glutamate turnover in healthy elderly and patients with chronic obstructive pulmonary disease. Nutrition 2006;22:496-503.

16. Matthews DE, Marano MA, Campbell RG. Splanchnic bed utilization of glutamine and glutamic acid in humans. Am J Physiol 1993;264:E848-54.

17. Rutten EP, Engelen MP, Schols AM, et al. The effect of repeated ingestion of glutamate or glutamine on plasma glutamate levels. Clin Nutr 2003;22:S27.

18. Gross NJ. The GOLD standard for chronic obstructive pulmonary disease. Am J Respir Crit Care Med 2001;163:1047-8.

19. Picado C, Deulofeu R, Lleonart R, et al. Lipid and protein metabolism in asthma. Effects of diet and corticosteroid therapy. Allergy 1999;54:569-75.

20. Steiner MC, Barton RL, Singh SJ, et al. Bedside methods versus dual energy X-ray absorptiometry for body composition measurement in COPD. Eur Respir J 2002;19:626-31. 
21. Kyle UG, Bosaeus I, De Lorenzo AD, et al. Bioelectrical impedance analysis-part I: review of principles and methods. Clin Nutr 2004;23:1226-43.

22. Clausen JL, Coates AL, Quanjer PH. Measurement of lung volumes in humans: review and recommendations from an ATS/ERS workshop. Eur Respir J 1997; 10:1205-6.

23. Bergstrom L. Muscle electrolytes in man. Determination by neutron activation analysis on needle biopsy specimens. A study on normal subjects, kidney patients, and patients with chronic diarrhea. Scand J Clin Lab Invest 1962;68:7-110.

24. Van Eijk HMH, Rooyakkers DR, Deutz NEP. Rapid routine determination of amino acids in plasma by high-performance liquid chromatography with a $2-3 \mu \mathrm{m}$ Sperisorb ODS 2 column. $J$ Chromatogr 1993;620:143-8.

25. Talmadge RJ, Roy RR. Electrophoretic separation of rat skeletal muscle myosin heavy-chain isoforms. J Appl Physiol 1993; 75:2337-40.

26. Vandeputte C, Guizon I, Genestie-Denis I, et al. A microtiter plate assay for total glutathione and glutathione disulfide contents in cultured/isolated cells: performance study of a new miniaturized protocol. Cell Biol Toxicol 1994;10:415-21.

27. Graham TE, Sgro V, Friars D, et al. Glutamate ingestion: the plasma and muscle free amino acid pools of resting humans. Am J Physiol Endocrinol Metab 2000;278:E83-9.

28. Rutten EP, Engelen MP, De Castro CL, et al. Decreased whole body glutamate turnover in elderly and patients with chronic obstructive pulmonary disease (COPD). J Nutr 2005;135: 2166-70.

29. Rutten EP, Engelen MP, Schols AM, et al. Skeletal muscle glutamate metabolism in health and disease: state of the art. Curr Opin Clin Nutr Metab Care 2005;8:41-51.

30. Medved I, Brown MJ, Bjorksten AR, et al. N-acetylcysteine enhances muscle cysteine and glutathione availability and attenuates fatigue during prolonged exercise in endurance-trained individuals. J Appl Physiol 2004;97:1477-85.

31. Gibala MJ, Peirce N, Constantin-Teodosiu D, et al. Exercise with low muscle glycogen augments TCA cycle anaplerosis but impairs oxidative energy provision in humans. J Physiol 2002;540:1079-86.

32. Mourtzakis M, Graham TE. Glutamate ingestion and its effects at rest and during exercise in humans. J Appl Physiol 2002;93: 1251-9.

33. Stegink LD, Filer Jr LJ, Baker GL. Plasma glutamate concentrations in adult subjects ingesting monosodium L-glutamate in consomme. Am J Clin Nutr 1985;42:220-5.

34. Romijn JA, Godfried MH, Hommes MJ, et al. Decreased glucose oxidation during short-term starvation. Metabolism 1990;39: 525-30.

35. Giesecke K, Magnusson I, Ahlberg M, et al. Protein and amino acid metabolism during early starvation as reflected by excretion of urea and methylhistidines. Metabolism 1989;38: 1196-200. 